\title{
Microstructure of Twin-roll Cast Al-Mg-Sc-Zr Alloy
}

\author{
Miroslav Cieslar ${ }^{1}$, Jan Bajer ${ }^{1}$, Mariia Zimina ${ }^{1}$, Olexandr Grydin ${ }^{2}$ \\ ${ }^{1}$ Faculty of Mathematics and Physics, Charles University, Ke Karlovu 5, 12116 Prague 2, Czech Republic. E-mail: \\ cieslar@met.mff.cuni.cz,janbajer69@seznam.cz,m.zimina@seznam.cz \\ ${ }^{2}$ Faculty of Mechanical Engineering, University Paderborn, Pohlweg 47-49, 33098 Paderborn, Germany. E-mail: \\ olexandr.grydin@uni-paderborn.de
}

A model twin-roll cast Al-Mg-Sc-Zr alloy was prepared and the evolution of microstructure during a step-by-step isochronal annealing was characterized by electron microscopy and light optical microscopy. Inhomogeneous structure with significantly finer grains in the middle of the strip is generated by casting. Subsequent annealing up to $550{ }^{\circ} \mathrm{C}$ does not alter this grain-size mainly due to the presence of a fine dispersion of $\mathrm{Al}_{3}(\mathrm{Sc}, \mathrm{Zr})$ particles, which forms at annealing temperatures below $300^{\circ} \mathrm{C}$. Although these particles coarsen and partially transform at higher annealing temperatures their strengths as recrystallization inhibitors is sufficient to prevent the microstructure from a coarsening. Nevertheless, the beneficial contribution of fine precipitates to microhardness is fully suppressed by the annealing at high temperatures.

Keywords: Al-Mg-Sc-Zr, Twin-Roll Casting, Microstructure

\section{Acknowledgement}

The financial supports of project of the Czech Science Foundation 16-16218S is gratefully acknowledged.

\section{References}

[1] DENG, Y., YIN, Z., ZHAO, K., DUAN, J, HE, Z. (2012). Effects of Sc and Zr microalloying additions on the microstructure and mechanical properties of new Al-Zn-Mg alloys, J. Alloy. Compd. Vol. 530, pp 71-80.

[2] FULLER, C. B., SEIDMAN, D. N, DUNAND, D. C. (2003). Mechanical properties of Al(Sc,Zr) alloys at ambient and elevated temperatures. Acta Materialia, Vol. 51, pp 4803-4814.

[3] LEE, S., UTSUNOMIYA, A., AKAMATSU, H., NEISHI, K., FURUKAWA, M., HORITA, Z., LANGDON, T. G. (2002). Influence of scandium and zirconium on grain stability and superplastic ductilities in ultrafine-grained Al-Mg alloys. Acta Materialia. Vol. 50, pp. 553-564.

[4] VLACH, M., STULÍKOVÁ, I., SMOLA, B., ŽALUDOVÁ, N. (2010). Characterization of phase development in non-isothermally annealed mould-cast and heat-treated Al-Mn-Sc-Zr alloys. Mater. Charact. Vol. 61, pp. 14001405 .

[5] MÁleK, P., TURBA, K., CIESLAR, M., DRBOHLAV, I., KRUML, T. (2007). Structure development during superplastic deformation of an Al-Mg-Sc-Zr alloy. Mater. Sci. Eng. A, Vol. 462, pp. 95-99.

[6] LIAO, M., BELLINGER, N.C., KOMOROWSKI, J.P. (2003). Modeling the effects of prior exfoliation corrosion on fatigue life of aircraft wing skins.Int. J. Fatigue. Vol. 25, pp. 1059-1067.

[7] POKOVÁ, M., CIESLAR, M. ZIMINA, M. (2015). Grain refinement in Al-Mn-Fe-Si alloys by severe plastic deformation. Manufacturing Technology. Vol. 15, pp. 679-684.

[8] POKOVÁ, M., CIESLAR, M., LACAZE, J. (2012). TEM investigation of precipitation in Al-Mn alloys with addition of Zr. Manufacturing Technology. Vol. 12, pp. 212-217.

[9] OGUOCHA, I.N.A., ADIGUN, O.J., YANNACOPOULOS, S. (2008), Effect of sensitization heat treatment on properties of Al-Mg alloy AA5083-H116. J. Mater. Sci. Vol. 43, pp 4208-4214.

[10] SLÁMOVÁ, M., JANEČEK, M., CIESLAR, M. (2007). Effect of low temperature stabilization on the precipitation of a continuously cast Al-Mg-Si alloy. Mater. Sci. Eng. Vol. 462, pp. 375-379.

[11] BIROL, Y., KARLÍK, M. (2006). The interaction of natural ageing with straining in a twin-roll cast AlMgSi automotive sheet. Scripta Materialia. Vol. 55, pp. 625-628.

[12] XIN, S., TAN, L., GUANGMING, X. (2015). Composition Homogenization Evolution of Twin-Roll Cast 7075 Aluminum Alloy Using Electromagnetic Field. Rare Metal Mater. Eng. Vol. 44, pp 581-586.

[13] GRYDIN, O., OGINS'KYY, Y.K., DANCHENKO, V.M., BACH, F.-W. (2010). Experimental twin-roll casting equipment for production of thin strips. Metallurgical and Mining Industry. Vol. 2, pp. 348-354. 
[14] HÁJEK, M., VESELÝ, J., CIESLAR, M. (2007). Precision of electrical resistivity measurements. Mater. Sci. Eng A. Vol. 462, pp. 339-342.

[15] BIROL, Y. (2009). Recrystallization of twin-roll cast Al-Fe-Si foil stock processed without homogenization. $J$. Alloy. Compd. Vol. 488, pp. 112-116.

[16] POKOVA, M., ZIMINA, M., CIESLAR, M. (2015). The influence of ECAP on microstructure evolution of aluminium alloys during in-situ heating in TEM. Int. J. Mater. Res. Vol. 106, pp. 1-6.

\section{Paper number: M2016232}

Copyright $($ C 2016. Published by Manufacturing Technology. All rights reserved. 